\title{
Comparative Study of Homogeneous Class and Heterogeneous Class of Participation Level and Result Learning in System Reproduction Classes of SMA/MA
}

\author{
Kharisma Arby Ristiana Wati*, Sulistiyawati \\ Department Biological Education, UIN Sunan Kalijaga Yogyakarta \\ Jl. Marsda Adi Sucipto Yogyakarta \\ Email*: kharismaarby97@gmail.com
}

\begin{abstract}
The study is intended to determine how the differences between classes of homogeneous and class heterogeneous on the level of participation and the results of learning in class XI of the system of reproduction. The research is including field research with the approach of quantitative use study comparisons. Intake sample used technique purposive sampling and using three classes. the class is heterogeneous, class homogeneous male (M) and class heterogenous female (FM). Instruments retrieval of data using the data test multiple choice (posttest) and questionnaire level of participation. Mechanichal analysis of the data using a test statistic one way ANOVA and test Tukey as the test continued. The results of the study indicate that 1) the level of participation in class heterogeneous, class homogeneous male and class homogeneous female is not there differences in views of the value of the significant of 0,122 which means $0,122>0,05$ and $F_{\text {count }}$ of 2,185 $<F_{\text {table. }}$ 2) The result of study on class of heterogenous, class homogeneous male, class homogeneous female there are differences in view on the value of significant of 0,000 . Wich means that $0,000<0.05$ and $F_{\text {count }}$ amounted to 52,657> $\mathrm{F}_{\text {table, }}$ based on test Tukey class that has the value of the results of studying the best is the class of homogeneous male.
\end{abstract}

Keywords: homogeneous class, heterogeneous class, level participation, result learning

\section{INTRODUCTION}

Teaching and learning activities are one of the important activities in education. According to ki Hajar Dewantara education is an effort to advance the character, mind and body of the child, in order to advance the perfection of life, which is life and bring life to children in harmony with nature and society (Wahyudin, 2008). Education is a directed process for children to socialize. The nature of education itself as a normative science operation process. This value will give color to the social life of children in society and their lives to come. Education in the broadest sense must be interpreted that the development of children is influenced by family, community and institutional life. Planting the correct norms of behavior intentionally given to students who study in educational institutions (schools) (Sunarto, 2013).

Education in Indonesia generally applies coeducation or heterogeneous classes, but many schools also apply single sex education or homogeneous classes, especially schools based on religion, especially Islam. Co-education is education that puts students male and students female together or mixed in one class, while single sex education is education that divides students according to gender, so students who are female and female sex are separate classes. The division of classes by applying single sex education is carried out by most faith-based schools, because it is influenced by an understanding of medieval fiqh works which forbid many meetings between men and women in one place even forbidding the emergence of women in the public sphere (Zarkasyi, 2005).

Classroom arrangement with homogeneous or heterogeneous conditions based on sex in the learning process will provide a different learning experience for each student. In homogeneous classes, students are more free to interact with their peers because they have more in common. The more similarities, the closer the relationship between its members (Damsar, 2011). In heterogeneous classes the interactions that occur tend to be more crowded so as to make students not focus on the ongoing lesson. Also in heterogeneous classes students are not confident because of the opposite sex. Several studies mention that girls in one-sex-based schools have better learning achievement than girls in two-sex-based schools (Junariyah, 2014; Ika, 2013; Kipkorir, 2013; Baker, 2002; Lee \& Marks, 1990; Mael, 1998; Jimenez \& Lockheed, 1989). In this regard, they stated a number of things, namely (1) girls in a sex-based school feel more confident and empowered, (2) girls in a sex-based school need more effort to develop aspirations, and (3) boys dominate the two sex-based schools.

Other studies mention boys and girls in two-sexbased schools showing better learning achievement than boys and girls in one-sex schools (Bang \& Baker, 2013). In detail, Bang \& Baker states several things, including (1) girls consider science a difficult subject, (2) girls are not confident in their scientific process abilities, and (3) girls show poor achievements in science and mathematics. 
Research on attitudes conducted by Ye, Skoog and Zhu (2009) found that male students had more positive attitudes towards science, especially in physics and chemistry than female students, whereas female students had more positive attitudes toward biology. Kim and Lee's (1996) survey on the educational effects of camp science shows that male student participation is much higher than female student participation, which is $21.9 \%$. Kim and Chea (1997) also asserted that male students were higher than female students in terms of their participation in school science clubs. Research conducted by Rizki Amelia (2017) on the analysis of class participation of male and female students concluded that male students participated more actively in the class compared to female students. Material of the reproductive system in the learning of SMA / MA students especially in the human reproductive system is still considered taboo for some SMA / MA students so that there are still many of them ashamed and not active in class when learning the material, especially when shown reproductive organs. Mixed classes will laugh at each other between men and women. so they chose silence and were not active to ask. This will cause students to have a low desire to ask questions when they have to learn the reproductive system whose class is mixed with friends of the opposite sex. The results of interviews with students whose classes are separated between men and women are more enthusiastic when discussing the material of the reproductive system without the opposite sex. Students who are classmates with same-sex friends, have the freedom to discuss their reproductive organs so that they are more free and free to discuss.

Lack of enthusiasm of students in asking questions and being active in class indicates the lack of participation of students in learning. Student participation is the participation of students in an activity that is shown by physical and psychological behavior. Optimal learning will occur if students participate responsibly in the learning process. The activeness of students is shown by their participation. The activity can be seen from several behaviors such as listening, discussing, making something, writing reports, and so on. Student participation is needed in setting goals and in learning and teaching activities (Hasibuan \& Moedjiono, 2006). Lack of student participation in participating in lessons will also have an impact on learning results. Learning results are abilities possessed by students after they receive their learning experience (Sudjana, 2009). Learning results are changes in overall behavior that a person has. Changes in behavior are related to changes in cognitive, affective, psychomotor behavior. Therefore, the results of learning not only in the form of mastery of knowledge, but also the skills and skills in seeing, analyzing and solving problems, making plans and carrying out the division of work from learning activities thus get a rating, assessment is not only done in writing but also verbally and assessment of deeds. Based on the problems, the purpose of this study is 1) Knowing how the difference between homogeneous classes and heterogeneous classes based on gender on the level of student participation. 2) Knowing how the difference between homogeneous classes and heterogeneous classes based on gender on student learning result.

\section{METODOLOGY}

This research was conducted at SMA Ali Maksum and MA Nurul Ummah class XI in the even semester of the 2018/2019 school year, around April-May. This type of research is field research, with a quantitative approach through comparative studies. Comparative study is a form of descriptive research that compares two or more of two situations, events, program activities, etc. that are similar or almost the same (Sukmadinata, 2013). The independent variables in this study are homogeneous classes and heterogeneous classes based on gender. The dependent variable in this study is the level of participation and learning outcomes in the cognitive domain of class XI students.

The population at this study were all students of class XI MA Nurul Ummah and all class XI SMA Ali Maksum even semester 2018/2019. The sample used in this study is in the form of units (classes), namely 1 class in MA Nurul Ummah as a heterogeneous class and 2 classes in SMA Ali Maksum as a heterogeneous class. Purposive sampling was used to take sample. This technique is used to achieve certain goals that are in accordance with the interests and the consideration of researchers (Syafi'I, 2005). The reason for taking SMA Ali Maksum and MA Nurul Ummah as samples is because these two schools have the same background, that is the Islamic boarding school and have the same number of students in their class. Data collection instruments used in this study were test sheets and questionnaire sheets. Test sheets are used to measure student learning result in the cognitive domain $\mathrm{C} 1$ - C4. Question sheets are given to students after the material is given. The questionnaire sheet used in this study was in the form of a student participation level questionnaire sheet. The data obtained from the questionnaire sheets were then analyzed descriptively using a scoring technique with the formula of the relative frequency distribution, that is:

Where is:

$$
P=\frac{f}{N} \times 100 \%
$$

$P \quad=$ Number of percentage of learning participation

$\mathrm{n}=$ Number of respondents' answers score

$\mathrm{N} \quad=$ Number of ideal answer scores (Sujidono, 2015).

The results of the scoring are then identified by the participation rate assessment category table. Researchers 
use four categories, that is, very high, high, low, and very low.

Table 1. Category.

\begin{tabular}{lll}
\hline Score & Interval (\%) & Category \\
\hline 1 & $25.00 \%-43.75 \%$ & Very low \\
2 & $43.76 \%-62.50 \%$ & Low \\
3 & $62.51 \%-81.25 \%$ & High \\
4 & $81.26 \%-100.00 \%$ & Very high \\
\hline
\end{tabular}

\section{RESULT AND DISCUSSION}

\section{Research Result}

1. Differences in level of Participation

a) Description data level of participation

The results of measuring the level of participation of students in heterogeneous classes, homogeneous classes of male, and homogeneous classes of female can be seen in the following table.

Table 2. Data on Student Participation Rate Results.

\begin{tabular}{lllll}
\hline No. & Aspect & $\begin{array}{c}\text { heterogeneous } \\
\text { class } \\
(\%)\end{array}$ & $\begin{array}{c}\text { homogeneous } \\
\text { classes M } \\
(\%)\end{array}$ & $\begin{array}{c}\text { homogeneous } \\
\text { classes FM } \\
(\%)\end{array}$ \\
\hline 1 & $\begin{array}{l}\text { Amount } \\
\text { of }\end{array}$ & 20 & 20 & 16 \\
2 & $\begin{array}{l}\text { students } \\
\text { Lowest } \\
\text { value }\end{array}$ & 66.67 & 55 & 64.17 \\
3 & $\begin{array}{l}\text { Highest } \\
\text { score } \\
4\end{array}$ & 94.17 & 85.83 & 85 \\
\hline
\end{tabular}

Percentage score of the student level participation is then interpreted into categories. Overall the frequency distribution of the level of participation students in heterogeneous classes, homogeneous classes for male, and homogeneous classes of female can be seen in the following figure.

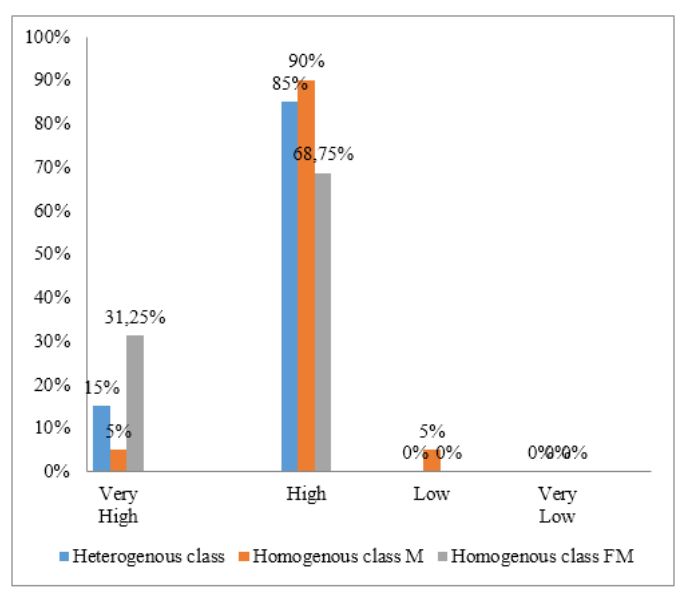

Figure 1. Histogram of the frequency distribution of students participation levels.

\section{b) Hypothesis Test}

Before the hypothesis test is performed, the normality test and homogeneity test are first performed as a prerequisite test. Based on the normality test of the three classes has a significance value of $0.200,0.200$ and 0.200 . These results have sig. $>0.005$ which shows normal distribution of data. Homogeneity test results have a significance value of $0.838>0.005$ which means homogeneous data. Furthermore, hypothesis testing can be done with One Way Anova. Hypothesis test results can be seen in the following table.

Table 3. Results of Analysis of Level Participation of Students with Anova Test.

\begin{tabular}{cccccc}
\hline $\begin{array}{c}\text { Level } \\
\text { Participati } \\
\text { on }\end{array}$ & $\begin{array}{c}\text { Sum of } \\
\text { Squares }\end{array}$ & Df $\begin{array}{c}\text { Mean } \\
\text { Square }\end{array}$ & F & Sig. \\
\hline $\begin{array}{c}\text { Between } \\
\text { Groups }\end{array}$ & 172.637 & 2 & 86.319 & 2.185 & .122 \\
Within & 2093.320 & 53 & 39.497 & \\
Groups & & & & \\
Total & 2265.957 & 55 & & & \\
\hline
\end{tabular}

Table 3. above shows that the significance value of the participation rate is 0.122 and the Fcount value is 2.185 and the Ftable is 3.17. The ANOVA test results showed that the probability of > 0.05 and Fcount < Ftabel so that $\mathrm{H}_{0}$ is received, or there is no significant difference between the three classes.

2. Difference in Learning Results

a) Description data of students learning result

Measurement of learning result of heterogeneous class students, homogeneous classes of male, and homogeneous classes of female can be seen in the following table.

Table 4. Student Learning Results Data.

\begin{tabular}{lllll}
\hline No. & Aspect & $\begin{array}{c}\text { Heteroge } \\
\text { neous class } \\
(\boldsymbol{\%})\end{array}$ & $\begin{array}{c}\text { Homogeneous } \\
\text { classes M } \\
(\%)\end{array}$ & $\begin{array}{c}\text { Homogeneous } \\
\text { classes FM } \\
(\%)\end{array}$ \\
\hline 1 & $\begin{array}{l}\text { Amount } \\
\text { of } \\
\text { students }\end{array}$ & 20 & 20 & 16 \\
2 & $\begin{array}{l}\text { Lowest } \\
\text { value }\end{array}$ & 25 & 50 & 70 \\
3 & $\begin{array}{l}\text { Highest } \\
\text { score } \\
4\end{array}$ & 80 & 95 & 90 \\
\hline
\end{tabular}

\section{b) Hypothesis Test}

Before the hypothesis test is performed, the normality test and homogeneity test are first performed as a prerequisite test. Based on the normality test of the three classes has a significance value of $0.080,0.096$ and 0.200 . These results have sig. $>0.05$ which shows the data are normally distributed. Homogeneity test results have a significance value of $0.102>0.05$ which means 
homogeneous data. Furthermore, hypothesis testing can be done with One Way Anova. Hypothesis test results can be seen in the following table.

Table 5. Results of Analysis of Student Learning Results with the ANOVA Test.

\begin{tabular}{lccccc}
\hline $\begin{array}{l}\text { Learning } \\
\text { result }\end{array}$ & $\begin{array}{c}\text { Sum of } \\
\text { Squares }\end{array}$ & Df & $\begin{array}{c}\text { Mean } \\
\text { Square }\end{array}$ & F & Sig. \\
\hline $\begin{array}{l}\text { Between } \\
\text { Groups }\end{array}$ & 13670.312 & 2 & 6835.156 & 52.657 & .000 \\
Within & 6879.688 & 53 & 129.805 & & \\
Groups & 20550.000 & 55 & & & \\
Total & & & & & \\
\hline
\end{tabular}

Table 5. above shows that the value of learning results has a significance of 0,000 and a value of Fcount of 52,657 and Ftable of 3.17. ANOVA test results showed that the probability of $\langle 0.05$ and $\mathrm{F}$ count $>$ Ftable, so it can be concluded that the three classes have unequal learning results and otherwise $\mathrm{H}_{0}$ is rejected. So,there are differences in learning results between the three classes. Next, a Tukey HSD test is performed to determine which groups are different and which are not. The results of the Tukey HSD test can be seen in the following table.

Table 6. Result test with the Tukey HSD Test.

\begin{tabular}{ccccc}
\hline $\begin{array}{c}\text { (I) } \\
\text { Class } \\
\mathbf{1 , 2 , 3}\end{array}$ & $\begin{array}{c}(\mathbf{J}) \\
\text { Class } \\
\mathbf{1 , 2 , 3}\end{array}$ & $\begin{array}{c}\text { Mean } \\
\text { Difference } \\
(\mathbf{I}-\mathbf{J})\end{array}$ & $\begin{array}{c}\text { Std. } \\
\text { Error }\end{array}$ & Sig. \\
\hline 1 & 2 & $-34.75000^{*}$ & 3.60285 & .000 \\
\cline { 2 - 5 } & 3 & $-29.18750^{*}$ & 3.82140 & .000 \\
\hline 2 & 1 & $34.75000^{*}$ & 3.60285 & .000 \\
\cline { 2 - 5 } & 3 & 5.56250 & 3.82140 & .320 \\
\hline 3 & 1 & $29.18750^{*}$ & 3.82140 & .000 \\
\cline { 2 - 5 } & 2 & -5.56250 & 3.82140 & .320 \\
\hline
\end{tabular}

Explan :

Class 1 : Heterogenous class

Class 2 : Homogenous class of male

Class 3 : Homogenous class of female

The results of Tukey HSD's further tests revealed that the class that had the best value was the Homogeneous PA class. This is seen from the sign (*) in the mean comparison line.

\section{Discussion}

\section{Differences in participation levels}

The level of participation of Dimyati and Mudjiono (2013) participation includes willingness, attention in an activity. Student participation means the participation of students in an activity that is shown by their physical and psychological behavior. Optimal learning will occur if students participate responsibly in the learning process.
The activeness of students is shown by their participation. The activity can be seen from several behaviors such as listening, discussing, making something, writing reports, and so on. Student participation is needed in setting goals and in learning and teaching activities (Hasibuan \& Moedjiono, 2006). The level of participation in this study was measured through a questionnaire containing several statements. The aspects used in measuring the level of student participation consist of the participation of students receiving lessons, the participation of students in class discussion activities, the participation of students in presentations, and the participation of students in doing assignments / questions.

Based on table 2. it is known that the heterogeneous class has an average percentage of participation rate of $75.13 \%$, homogeneous class PA has an average percentage of participation rate of $72.63 \%$. The results of testing with one way ANOVA revealed that the significance value of the participation rate was 0.122 and the Fcount value was 2.185. The ANOVA test results showed that the probability of $>0.05$ and Fcount $<$ Ftable so that $\mathrm{H}_{0}$ is accepted. This means that there are no differences in the scores of heterogeneous class participation rates, homogeneous male class and homogeneous female class. The level of participation of the three classes has the highest order, namely the homogeneous female class, then the heterogeneous class and finally the homogeneous male class. All three can be categorized as having a high level of participation. This can be influenced by the same learning, namely the presentation discussion method, thus requiring students to play an active role in discussion activities. One of the factors of participation according to Malone in Sutikno (2004) is that there is relevance to the needs of students. This reproductive system material is needed by students to get to know their organs and organs that are different from the opposite sex. According to gender stereotypes when students are in the position of puberty, both men and women experience confusion and worry about what happens to their bodies (Santrock, 2012). So they will be interested when discussing material related to the events of puberty and what is subsequently experienced by their bodies.

According to the sociology perspective, class is part of the micrososiology that examines the life of social groups in schools with the overall dynamics that occur (Karsidi, 2008). Classrooms have a standard definition of social groups because a group of people who have a shared awareness of membership and interact with each other (Horton \& Hunt, 1984). The socialization that occurs in schools is a socialization based on planning, where all learning objectives, materials, processes, and assessments have been carefully constructed, so that all are measurable and can be evaluated and monitored (Damsar, 2011). At school there are socialized values, namely the value of independence, the value of 
achievement, universalisme, and the value of specificity. Grouping students according to gender according to Omrod in Ramanda \& Khairat (2017) students who come from homogeneous classes have the ability to achieve socially responsible behavior higher than students who come from heterogeneous classes because they are in an environment that demands them to be more to be responsible. When students are sexsegregated this makes them more independent and responsible. Grouping students according to sex will make students more actively participate in class and able to do social responsibility. In addition, according to Desmita (2011) the ability of adolescents to achieve responsible social behavior is inseparable from the social interactions carried out by adolescents with their friends. Friends and groups provide encouragement for adolescents to take on their roles and responsibilities. Grouping students by sex will minimize the aggression of male students and maximize the attitudes of women who are considered to be quiet.

The results of the homogeneous female class questionnaire assessment got the highest average value compared to the homogeneous male class or heterogeneous class. This is caused by the verbal ability of women is better than the verbal ability of men. Men are more dominant in physical language or physically aggressive (Santrock, 2012). When learning homogeneous female class discuss more or ask questions, whereas homogeneous male class do more physical activities even though they remain in the classroom, such as playing with friends or playing with items that are around them.

\section{Differences in learning results}

Learning results are abilities possessed by students after receiving a learning experience (Sudjana, 2009). Learning results are abilities obtained by children after going through learning activities. The process of programmed and controlled learning activities called learning activities or instructional activities, the learning objectives have been created in advance by the teacher. Children who succeed in learning activities are those who succeed in achieving learning goals or instructional goals (Abdurrahman, 2003). Learning results in this study were measured on cognitive aspects using multiple choice questions that are limited to the cognitive domain C1-C4. Questions are given to students when the reproductive system material has been finished being discussed in learning. Based on the results of the analysis in table 4. Heterogeneous classes have an average value of learning results of 49.25 , homogeneous male class have an average of 84 , and homogeneous female class of 78.44. the results of the analysis using one-way ANOVA show a significance value of $0.00<0.05$ which is a Fcount value of 52.657> Ftable 3.17. This means that $\mathrm{H}_{0}$ is rejected or there are differences in learning results in all three classes
Further test analysis using Tukey test showed that homogeneous male class has the best value from the class results homogeneous or heterogeneous female class. According to Gurian (2011) it is known that men are superior in the mastery of science. Biology is one branch of science. In addition, it is caused by learning experiences with homogeneous learning groups in sex and discussing the intimate parts of human organs, so that students have the freedom to exchange information and discuss material being taught. Research conducted by Macoby \& Jackin (1974) also found that teenage boys generally showed better performance in spatial visuo and mathematical abilities, while women were better at verbal tasks, such as writing sentences, correct spelling, reading and pronunciation. Halpern and LaMalay (2000) and Halpern (2004), also found that men were better in numerical abilities, while women were generally better at verbal ability tests. The existence of the data also shows that there are differences in tendencies between students and good communication of both having positive potential and mutual support in increasing understanding and results.

This study both homogeneous classes have higher learning results than heterogeneous classes. This is as found by Baker et al. (1995) that men are more successful in the learning process than women in homogeneous classes. The difference in learning achievement is also influenced by the individual characteristics of students, the ability to complete tasks by students, and the learning styles of students (Rahmani \& Jahanbakhsh, 2012, Yilmaz \& Orhan, 2010). Biologically, the differences in brain structures allow male students and female students to differ in several ways such as the ability to process, respond to information, and store long-term information. Sasser (2010) reports that limbic system regions in men and women have different structures. Men have a bigger amygdala than women. The amygdala is the part of the brain that plays a role in processing and memory of emotional reactions, in men will frighten fear and trigger protective aggression (Brizendine, 2010). In women, the Broca area works more actively than in men. This broca area that moves to speak and process the structure of grammar and word production. This causes the tendency of women to be more active in verbal communication (Gurian, 2011). In thebrain female, the hormones estrogen, progesterone, and oxytocin affect the brain's circuits for typical female behavior. in the male brain the hormones that play a role influence typical male behavior, namely testosterone, vasopressin, and a hormone called MIS. The effects of hormones on the brains of men and women are enormous. Men use different parts of the brain to process information about space and solve emotional problems, where brain circuits are connected to their muscles differently, especially in the face. It is also known that male brains have 2.5 times the area shown for sexual desire in their hypothalamus (Brizendine, 2010). These things can make 
homogeneous PA students get better grades than other classes.

Generally, learning results according to Muhibbin Syah (2010) are influenced by three factors, namely internal factors of students in the form of biological and psychological conditions, where these factors have been explained above. Then the external factors of students in the form of environmental conditions of students. In the homogeneous male classroom environment conditions and Homogeneous female class are known to be more conducive and active learning, so that it can influence the achievement of results. Furthermore, the learning approach factor, these factors both classes use the discussion learning method of presentation. But in daily application the results of interviews with subject teachers mention that it is easier to teach homogeneous classes compared to heterogeneous classes. This is caused by the language that can be absorbed by men and women differently, so that in each class of men or even women's classes the delivery of material in different languages.

According to John Bruer in Woolfoolk (2009) psychologists only find differences in boys who are superior to girls in mentally rotating objects. In addition, according to Fennema and Peterson (1988) the facts of the field show that there are boys who are developing or not, girls who are strong in mathematics and experiencing difficulties, boys who are good in the language, and some are not. Some evidence that activities used to teach mathematics and science might make a difference for girls. Elementary school girls may be better in mathematics and science when they learn with cooperative activities rather than competitive activities. During teaching it is recommended to offer various ways of learning, so that all students have access to important results of teacher teaching. Teacher encouragement and attitude will also make a difference for both male and female students who need persuasive encouragement to make them confident to get the best results.

\section{CONCLUSION}

Different levels of participation between heterogeneous classes, homogeneous male class and homogeneous female class tend to be absent. Judging from the Anova test results of 2.185 with a significance of 0.122 , which means that the probability $>0.05$, while the difference in learning outcomes between heterogeneous classes, homogeneous PA classes and homogeneous PI classes there are significant differences. Judging from the Anova test results of 52,657 with a significance of 0,000 , which means the probability $<0.05$.

\section{REFERENCES}

Abdurrahman, M. 2003. Pendidikan Bagi Anak Berkesulitan Belajar. Jakarta: Rineka Cipta.
Amelia, R. 2017. Analisis Partisipasi Kelas Peserta didik Laki-laki dan Peserta didik Perempuan. Jurnal Perempuan, Agama dan Jender Vol.16 No.1

Baker, D. \& Riordan, et al. 1995. The effects of sex-grouped schooling on achievement: the role of national context. Comparative Educational Review. 39(4): 468

Baker, D. 2002. Good Intention: An Experiment in Middle School Single-Sex Science and Mathematics Classrooms with High Minority Enrollment. Journal of Women and Minorities in Science and Engineering, 8:1-23.

Bang, E. \& Baker, D.R. 2013. Gender Differences in Korean High School Students' Science Achievements and Attitudes Towards Science in Three Different School Settings. Mevlana International Journal of Education (MIJE), (Online), 3(2):2742, (http://mije.mevlana.edu.tr/

Brizendine, L. 2010. Male Brain: Mengungkap Misteri Otak Lakilaki. Jakarta: Ufuk Press

Damsar. 2011. Pengantar Sosiologi Pendidkan. Jakarta: Prenada media.

Desmita, D. 2011. Psikologi Perekembangan Peserta Didik: Panduan bagi Orang Tua dan Guru dalam Memahami Psikologi Anak Usia SD, SMP, dan SMA. Bandung: remaja Rosdakarya.

Dimyati \& Mudjiono. 2013. Belajar dan pembelajaran. Jakarta: Rineka Cipta.

Fennema, E. \& Peterson, P. 1988. Effective Teaching for Boys and Girl: The Same or Difeerent? Dalam D.Berliner \& B. Rosenshine (Eds). Talks to Teacher. New York: Random House.

Gurian,M. 2011. Boys and Girl Learn Differently: A Guide for Teacher and Parents. San Francisco: Jossey Bass

Halpern, D. F. 2004. A Cognitive-process Taxonomy for Sex Differences in Cognitive Abilities. Current Directions in Psychology Sciense. 13 (4). 135-139

Halper, D. F., \& LaMay. M. L. 2000. The Smarter Sex: A Critical review of Sex Differences in Intelegence. Educational Psychology Review.,12 (2), 229-246

Hasibuan dan moedjiono. 2002. Proses Belajar Mengajar. Bandung: Remaja Rosdakarya

Ika, Lisa.F. 2013. Perbandingan Hasil Belajar berdasarkan Gender pada Mata Pelajaran Biologi Materi Sistem Peredaran Darah Manusia Kelas XI IPA MA Matholi'ul Huda Bugel Jepara Tahun Ajaran 2012/2013. Skripsi. Semarang: UIN Walisongo.

Jimenez, E. \& Lockheed, M.E. 1989. Enhancing Girls' Learning Through Single-Sex Education: Evidence and Policy Conundrum. Educational Evaluation and Policy Analysis, 11:117-147.

Junariyah, N. 2014. Studi Komparasi Prestasi Belajar Tarikh Antara Peserta didik Kelas Campuran Dengan Kelas Terpisah Putra Putri Di Kelas Vii Smp Muhammadiyah 8 Surakarta Tahun Pelajaran 2013/2014. Skripsi. Surakarta: UMS

Karsidi, R. 2008. Sosiologi Pedidikan. Solo: LPP UNS

Kim, S. W. \& Chea, S. H. 1997. The Present Operational Status of Science Club Activities in Secondary School and Improvement Schemes (in Korean). Journal of the Korean Association for Research in Science Education, 17, 511-524.

Kim, S. W. \& Lee, H. K. (1996). The Present Operational Status and Educational Effects of Science Camp in Korea (in Korean). Journal of the Korean Association for Research in Science Education, 16, 175-189.

Kipkorir, B.P. 2013. Differences in Performance Between Boys and Girls in Secondary School Science Subjects in Keiyo 
District, Kenya. International Journal of Advanced Research, (Online), 1(5):449-454, (http://www.journalijar.com)

Lee, V.E., \& Marks, H.M. 1990. Sustained Effects of the SingleSex Secondary School Experience on Attitudes, Behaviors, and Values in College. Journal of Educational Psychology, 82: $578-592$

Maccoby, E., \& Jacklin, C. 1974. The Psychology of Sex Differeces. Vol. 1. Stanford, CA: Stanford University Press.

Mael, F.A. 1998. Single-Sex and Co-educational Schooling: Relationships to Socioemotional and Academic Development. Review of Educational Research, 68:101-129.

Rahmani \& Jahanbakhsh. 2012. Learning Styles and Academic Achievement: a Case Study of Iranian High School Girls' Students. Procedia-Social and Behavioral Sciences, 51:1030 1034.

Rahmanda,S \& Khairat,I. 2017. Perbdaan Kematangan Peserta didik yang Berasal dari Sekolah Homogen dan Sekolah Heterogen. Jurnal Kajian Bimbingan dan Konseling, 2(4), 2017, 148-156

Sasser, L. 2010. Brain Difference Between Gender. Gender Differences In Learning. Genesis, 5, 1-2

Sudijono, A. 2015. Pengantar Statistik Pendidikan. Jakarta: Rajawali Pers
Sudjana, Nana. 2009. Penilaian Hasil Proses Belajar Mengajar. Bandung: PT. Remaja Rosda Karya.

Sukmadinata, N. S. 2012. Metode Penelitian Pendidikan. Bandung: PT Remaja Rosdakarya.

Sutikno, Sobry. 2004. Belajar dan Pembelajaran. Bandung: Prospect

Syah, Muhibbin. 2010. Psikologi Pendidikan dengan Pendekatan Baru. Bandung: PT. Remaja Rosdakarya

Wahyudin. 2008. Pengantar pendidikan. Jakarta: Universitas Terbuka.

Woolfolk, A. E. 2009. Educational Psychology. Yogyakarta: Pustaka Pelajar.

Ye, R., Skoog, G., \& Zhu, Y. 2000. Science Learning in Chinese Secondary Schools. Fourth International Conference of thrahmanie Learning Sciences 129-130.

Yilmaz, M. \& Orhan, F. 2010. High School Students Educational Usage of Internet and Their Learning Approaches. World Journal on Educational Technology, 2(2):100-112.

Zarkasyi, Abdullah S. 2005. Gontor dan Pembaharuan Pendidikan Pesantren. Jakarta: Raja Grafindo Perkasa. 
THIS PAGE INTENTIONALLY LEFT BLANK 